Omni-Akuatika, 17 (1): 46 - 59, 2021
ISSN: 1858-3873 print / 2476-9347 online
Research Article
journal homepage: http://ojs.omniakuatika.net

\title{
Underwater noise of commercial vessels in Nusakambangan Strait and the relationship with distance
}

\author{
Amron Amron ${ }^{1 *}$, Rizqi Rizaldi Hidayat ${ }^{1,2}$, Yessy Hurly Sefnianti ${ }^{1}$, Ratna Juita Sari ${ }^{1}$ \\ ${ }^{1}$ Department of Marine Science, Jenderal Soedirman University. Jl. dr. Soeparno Kampus Unsoed \\ Karangwangkal Purwokerto 53123 INDONESIA \\ ${ }^{2}$ Center for Maritime Bioscience, Jenderal Soedirman University, Jl. dr. Soeparno Kampus Unsoed \\ Karangwangkal Purwokerto 53123 INDONESIA
}

${ }^{*}$ Corresponding author: amron@unsoed.ac.id

Received 7 June 2021; Accepted 25 June 2021; Available online 30 June 2021

\begin{abstract}
The existence of shipping activities can produce noise with certain characteristics as a main source of noise pollution in the waters. This research aimed to study the sound characteristics (frequency and sound pressure levels) of various type of commercial vessels crossing the Nusakambangan Strait, its relationship to the distance, and their potential impact to the marine biota. Noise frequency and sound pressure level were determined by spectral and envelope analysis from sound recording by hydrophone, while the type of vessel that produces noise and the distance from receiver were analyzed based on video recording. Relationship between frequency and sound pressure level to the distance were analyzed using simple linear regression. Results showed that frequency of noise is varied more clearly compared to the sound pressure level $(1.7-20 \mathrm{kHz}$ and $93.8-117.8 \mathrm{~dB}$ re $1 \mu \mathrm{Pa}$ respectively) for each type of vessel (ro-ro ferry, small fishing boat, small ferry, tug boat and pilot boat) based on the size of the ship, engines type and power, loading capacity and vessels speed. Sound characteristics changed based on distance, where the frequency of sound increases $\left(0.04-34.28 \mathrm{~Hz}^{-\mathrm{m}^{-1}}\right)$ and different things for sound pressure level $\left(0.04-0.11 \mathrm{~dB}\right.$ re $\left.1 \mu \mathrm{Pa} \mathrm{m} \mathrm{m}^{-1}\right)$. Estimated source level also differ from one ship to another $(105-128 \mathrm{~dB}$ re $1 \mu \mathrm{Pa})$. The existence of ship noise has the potential impacts on the presence of marine biota in these waters.
\end{abstract}

Keywords: vessel noise, frequency, sound pressure level, vessel type, Nusakambangan Strait

\begin{abstract}
ABSTRAK
Keberadaan kegiatan pelayaran dapat menghasilkan kebisingan dengan karakteristik tertentu sebagai sumber utama pencemaran suara di perairan. Penelitian ini bertujuan untuk mempelajari karakteristik suara (frekuensi dan sound pressure level)) berbagai jenis kapal komersial yang melintasi Selat Nusakambangan, hubungannya dengan jarak, dan potensi dampaknya terhadap biota laut. Frekuensi dan sound pressure level derau ditentukan dengan analisis spektral dan envelope dari rekaman suara menggunakan hidrofon, sedangkan jenis kapal yang menghasilkan kebisingan dan jarak dari hidrofon dianalisis berdasarkan rekaman video. Hubungan antara frekuensi dan sound pressure level terhadap jarak dianalisis menggunakan regresi linier sederhana. Hasil penelitian menunjukkan bahwa frekuensi derau bervariasi lebih signifikan dibandingkan dengan sound pressure level (masing-masing 1,7 - 20 kHz dan 93,8 -117,8 dB re $1 \mu \mathrm{Pa}$ ) untuk setiap jenis kapal (kapal penyeberangan,, kapal nelayan kecil, kapal penyeberangan kecil, kapal tunda dan kapal pandu) berdasarkan ukuran kapal, jenis dan tenaga mesin, kapasitas muat dan kecepatan kapal. Karakteristik suara berubah berdasarkan jarak, dimana frekuensi suara meningkat $\left(0,04-34,28 \mathrm{~Hz} \cdot \mathrm{m}^{-1}\right)$ dan hal yang berbeda untuk tingkat tekanan suara $\left(0,04-0,11 \mathrm{~dB}\right.$ re $\left.1 \mu \mathrm{Pa} \mathrm{m}^{-1}\right)$. Perkiraan source level juga berbeda antara satu kapal dengan kapal lainnya (105-128 dB re $1 \mu \mathrm{Pa}$ ). Adanya kebisingan kapal berpotensi berdampak terhadap keberadaan biota laut di perairan tersebut.
\end{abstract}

Kata kunci: derau kapal, frekuensi, sound pressure level, tipe kapal, Selat Nusakambangan 


\section{Introduction}

Indonesia is an archipelago country that has diverse resources requires vessel as a sea transportation to optimize the potential. Shipping for economic activities produce noise with certain characteristics (see McKenna et al., 2012; Erbe, 2002; Kipple \& Gabriele, 2004; Hildebrand, 2004; Amoser et al., 2004; Blackwell \& Greene, 2006; Hildebrand, 2009; Pine et al., 2016; Triwahyanti et al., 2018). Ships as a main transportation have developed dramatically due to the economic, trade and technological developments influencing an increase in the contribution of noise as one of the pollution sources in the waters. Shipping activity on a global scale is a major contributor to noise in waters (Hatch et al., 2008; McKenna et al., 2012; Soares et al., 2020) in addition to other sources of noise pollution such as marine biota (see Ladich, 2015; Amron et al., 2017; McKenna et al., 2017; Amron et al., 2018; Bussmann et al., 2020; Halliday et al., 2020) and physical processes in the waters (see Sanjana et al., 2010; Vargas-Salinas \& Amézquita, 2014; McKenna et al., 2017; Amron et al., 2020; Zhang et al., 2020).

As a main source of noise pollution in the waters, the sound of vessel is generally produced by propeller, main engine, auxiliary engine, flow noise, etc. (Pazara et al., 2018). Variations of ship noise depend heavily on the propulsion system, and the propeller (Ross, 2005). This mechanical system produces noise based on the characteristics of the ship and engine type (McKenna et al., 2012). Small ships that have high-speed engines and propellers generally produce higher frequency (Erbe, 2002), while large ships produce lower frequency noise (McKenna et al., 2012). The sound of the ship will become more complex when the ship is operating (Kozaczka et al., 2007), where propellers and various types of engines and their parts will work together that cause noise is a combined effect from various sources (Zhang \& Meng, 2018). The strongest source of noise is usually the propeller when rotating (Donald Ross \& Kuperman, 1989). The engine produces noise with narrow band frequencies (Arveson \& Vendittis, 2000; Trevorrow et al., 2008), where the frequency produced ranges from $0.1-1 \mathrm{kHz}$ (Viola et al., 2017). Noise cavitation will increase as the ships speed, size and load increase (Donald Ross \& Kuperman, 1989; Scrimger \& Heitmeyer, 1991; Hamson, 1997; Trevorrow et al., 2008). In addition, the sound characteristics of both frequency and intensity will change in line with the change in distance due to the operation of the vessel (see Sutin et al., 2010; Fillinger et al., 2011; McKenna et al., 2012; Halliday et al., 2017; Jones et al., 2017; Ahmad et al., 2018 Peng et al., 2018; Enguix et al., 2019)

The presence of noise in the aquatic environment at certain level (low frequency to 20 $\mathrm{kHz}$, and low to high sound pressure level) will affect the existence of biota not only to marine mammal but also some types of aquatic organisms (Popper \& Hawkins, 2016; Soares et al., 2020). Several studies report that anthropogenic noise make pressure on marine mammal such as stress (Wright et al., 2011; Rolland et al., 2012; Castellote et al., 2012; Allen \& Angliss, 2013; Dunlop et al., 2017; Williams et al., 2019), critical life functions (Wright et al., 2011), changes in behavior (Williams et al., 2002; Nowacek et al., 2007; Christiansen et al.,

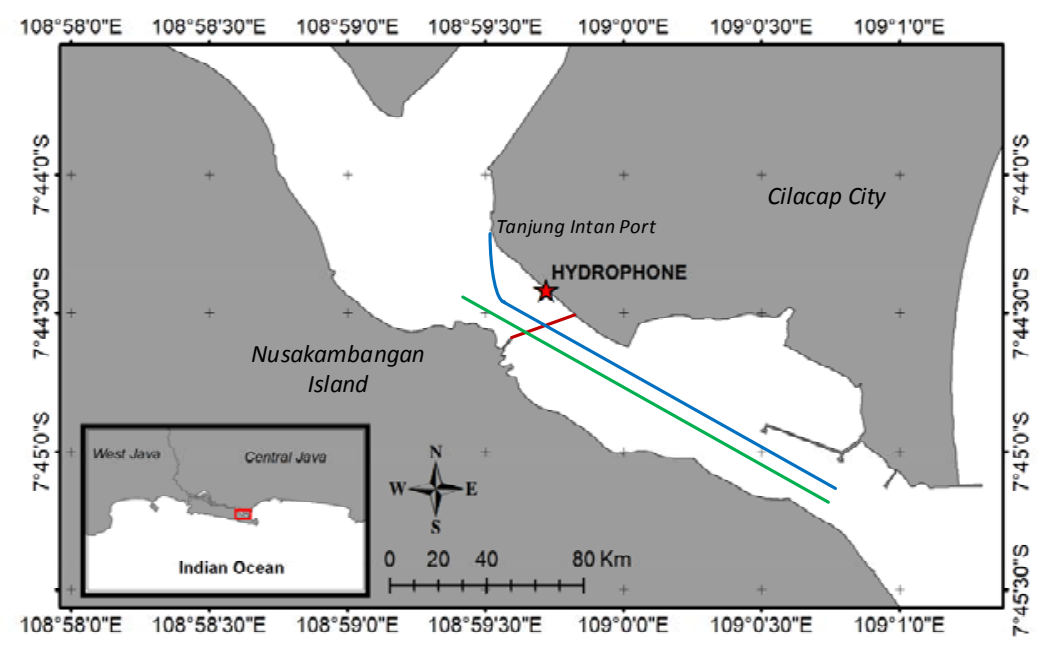

Figure 1. Recording's site. Solid lines represent to the shipping lane for ro-ro and small ferries (red), tug and pilot boats (blue), and small fishing boat (green). 
2010; Chen et al., 2017; Halliday et al., 2017), damage in auditory system (Popper et al., 2003). physiological change (Holt \& Schusterman, 2007; Branstetter \& Finneran, 2008; Nachtigall \& Supin, 2014; Erbe et al., 2016; Kastelein et al., 2019), other physiological effects (Tougaard et al., 2015), and population dynamics (Morton \& Symonds, 2002; Nabe-Nielsen et al., 2014). Meanwhile, for fish, some studies report that noise pollution has an impact on hearing ability (Amoser et al., 2004; Codarin et al., 2009); physical damage to the auditory system (McCauley et al., 2003), Stress (Wysocki et al., 2006; Kight \& Swaddle, 2011) and physiological effects (Casper et al., 2013; Di Franco et al., 2020).

The main objective of this research was to explore the sound characteristics of both frequency and sound pressure levels of various types of ships crossing the Nusakambangan Strait, Cilacap, Indonesia. Changes in sound characteristics to the distance of the ship with the receiver were also studied to determine the factors that influenced it and to estimate the absorption coefficient and source level of the ships noise. Prediction of the potential impacts of ship noise and their changes due to ships operating on aquatic biota both fish and marine mammal were also discussed in this study.

\section{Material and methods}

\subsection{Recording's site}

Ocean noise from five types of vessels that passing Nusakambangan Strait were recorded from MV. Perkasa 7 which anchored at Stasiun Pandu Pier, Cilacap, Indonesia ( $7^{\circ} 44^{\prime} 34^{\prime \prime} S$ and $\left.180^{\circ} 59^{\prime} 43^{\prime \prime} \mathrm{E}\right)$. These waters are the lane of vessels to entrance of Tanjung Intan Port
(Cilacap), to crossing Cilacap City and Nusakambangan Island and as the small fishing boat channel. Differences in the purpose of the voyage cause the lane of the ship is different for each type. Tug and pilot boats have a lane as inner and outer to Tanjung Intan Port. Ro-ro and small ferries have a lane to cross the strait from Cilacap city to Nusakambangan Island or conversely, while small fishing boats pass the strait with the specific lane (Figure 1).

\subsection{Recording systems}

Noise emitted by five types of vessels were collected using calibrated omnidirectional hydrophone (Sea Phone SQ26, sensitivity -194 $\mathrm{dB}$ re $1 \mathrm{~V} . \mu \mathrm{Pa}^{-1}, 20 \mathrm{~Hz}$ to $45 \mathrm{kHz}$ flat response) connected to sound recorder ( $20 \mathrm{~dB}$ gain, 16-bit, $4,410 \mathrm{~Hz}$ sampling rate and stored in .WAV file) from January $22-24,2018$ (Figure 2). Type of vessels passed the strait and the environment condition in the air and waters were recorded using HD CCTV camera (1080 MP). Both sound and video recordings were synchronized and connected to Zoom H1n digital flash recorder and displayed to LCD monitor. Sound and video recording was carried out continuously during the study.

\subsection{Data analysis}

Noise characteristics (frequency and sound pressure level) were determined by spectral and envelope analysis from sound recordings by hydrophone, while the type of vessel that produces noise were analyzed based on video recordings. The distance of the ship to the deployed hydrophone was a projection of the vessels movement that was recorded by CCTV camera to the map and validated based on the

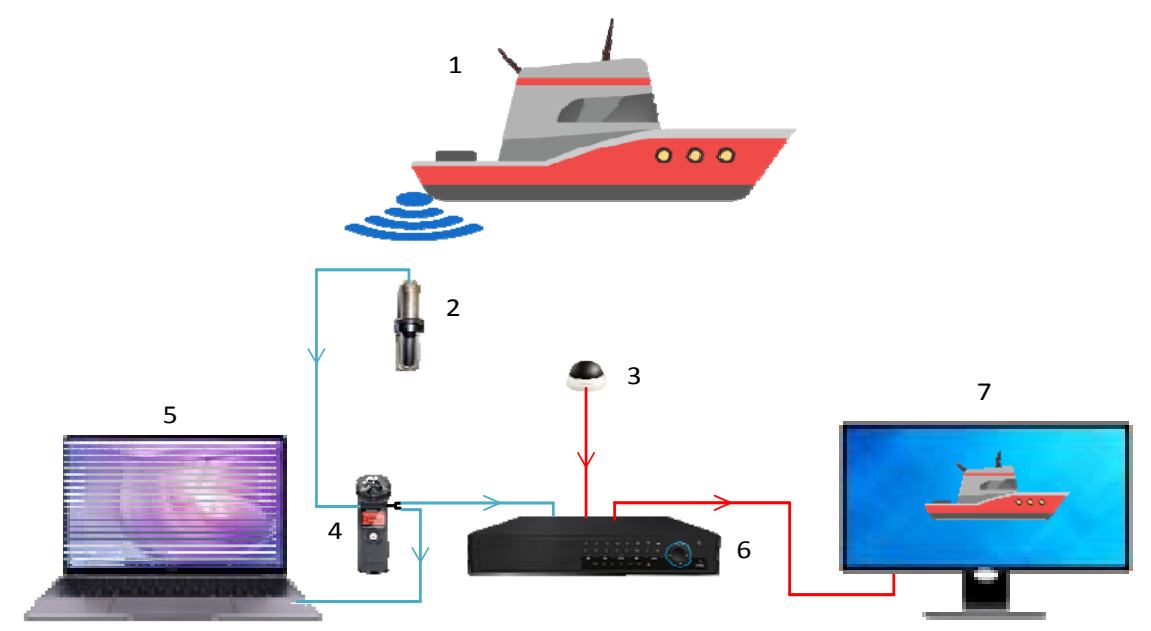

Figure 2. Recording systems. The blue and red lines represent the audio and video line. $(1-7)$ represent vessel, hydrophone, CCTV camera, sound recorder, personal computer, video recorder, and LCD monitor, respectively. 
speed of vessel. Specifications and uses of the vessel were analyzed descriptively based on observation, interview and data collection of vessels specification. Relationship between frequency and sound pressure level with the distance were analyzed using simple linear regression to determine the factors that influenced it and to estimate the absorption coefficient and source level of the ships noise.

\section{Results and Discussions}

\subsection{Type of vessels}

Most type of vessels which operating in the Nusakambangan Strait are categorized into the ro-ro ferry, small fishing boat, small ferry, tug boat, and pilot boat (Figure 3). Ro-ro ferry is a ship owned by the Indonesian Ministry of Law and Human Rights which functions as a main transportation for the Nusakambangan Prison needs (Figure 3A). Fishing boats are vessels used by fishermen for fishing and transporting the catch (Figure $3 \mathrm{~B}$ ). Small ferry are traditional boat used by the local community for crossing motorbike and passenger (Figure $3 \mathrm{C}$ ). Tugboats are vessels that are used to provide services to ships that will dock at Tanjung Intan Port, Cilacap. (Figure 3D). Meanwhile, a pilot boat is a ship that used to assist or pick up a pilot who will guide or finish guiding (Figure 3E). Differences in the function of each ship passing in the Nusakambangan Strait influence the differences in the shape, size, type of engine, engine power and operational speed. In general, the size of the ships payload ranges from $5-500$ GT with inboard and outboard engine types (10 to 1,500 Horse Power). The ships are operational with speed ranges from 8-30 Knot.

As a ro-ro ferry, the ship is equipped with an inboard engine with power of $450 \mathrm{HP}$. Related to this engine capacity, it can carry payloads that will reach 125 GT. This ferry serves the transportation of public servants, visitors and logistics needs from Cilacap City to Nusakambangan Prison, so that the shape and size of the vessel is specially designed for these purposes. The operational speed can reach 15 knot. Otherwise, another type of vessel that operating in these waters is small fishing boat. This boat is the smallest of all vessels that cross these waters because it functions only for smallscale fishing. This type of vessel is equipped with an outboard diesel engine with a power ranging from 15 to $25 \mathrm{HP}$. With the size and capacity of the engine, the operational exhaust of this boat can reach 8 knot. The characteristics of fishing boats are in accordance with The Minister of Marine Affairs and Fisheries Regulation No. 30/Permen/2012 where small fishing boats are 5 GT that are generally used by traditional fishermen to utilize the resources around the coastal waters. This vessel is generally built with fiberglass reinforced plastic (FRP) material which has a length of $10 \mathrm{~m}$, a maximum width of $1.20 \mathrm{~m}$, a height of $0.90 \mathrm{~m}$, a load of 0.40 , and a fuel tank of 25 litters. Another type of vessel is a small ferry. It aims as transportation for visitor mobilization (loading capacity 15 GT) from Cilacap City to Nusakambangan Island or reversely. This ferry is equipped with an outboard engine that is $25 \mathrm{HP}$ and can be operated at a speed of $12 \mathrm{knot}$. The size of the small ferry generally has a length of $10.30 \mathrm{~cm}$, a width of $1.20 \mathrm{~m}$ and a height of $0.90 \mathrm{~m}$.

The next type of vessels is tug and pilot boats. Both ships are as the facilities that must be owned by the port to serve the landing process of ships that will dock at the port. Tug boats that have a larger size are equipped with inboard engines with a large power, which ranges from 1,000 to $1,500 \mathrm{HP}$. It has a load capacity of 500 GT and can be operated at speeds of up to 13 knots. This boat is more than 70 meters long which serves to guide the ship that needs it, either to dock or leave the port by

Table 1. Sound pressure level, peak frequency, and frequency range based on the type of vessels

\begin{tabular}{|c|c|c|c|}
\hline Type of vessel & $\begin{array}{l}\text { Sound pressure level } \\
\text { (dB re } 1 \mu \mathrm{Pa} \text { ) }\end{array}$ & $\begin{array}{l}\text { Peak } \\
\text { frequency }(\mathrm{Hz})\end{array}$ & $\begin{array}{l}\text { Frequency range } \\
(\mathrm{Hz})\end{array}$ \\
\hline $\begin{array}{l}\text { Ro-ro ferry with inboard engine ( } 450 \mathrm{HP} \text {, } \\
125 \mathrm{GT}, 15 \mathrm{knot})\end{array}$ & $102.0-115.2$ & 955 & $495-2,259$ \\
\hline $\begin{array}{l}\text { Small fishing boat with outboard engine } \\
\text { (15 HP, } 5 \mathrm{GT}, 8 \mathrm{knot})\end{array}$ & $93.8-106.8$ & 1.742 & $777-6,765$ \\
\hline $\begin{array}{l}\text { Small ferry with outboard engine ( } 25 \mathrm{HP} \text {, } \\
15 \mathrm{GT}, 12 \mathrm{knot})\end{array}$ & $94.1-111.9$ & 3,181 & $\begin{array}{l}279-3.189 \text { and } \\
12,150-19,950\end{array}$ \\
\hline $\begin{array}{l}\text { Tug boat with inboard engine }(1,500 \mathrm{HP} \text {, } \\
500 \mathrm{GT}, 13 \mathrm{knot})\end{array}$ & $93.8-117.8$ & 347 & $170-2,629$ \\
\hline $\begin{array}{l}\text { Pilot boat with outboard engine ( } 500 \mathrm{HP} \text {, } \\
3,5 \mathrm{GT}, 30 \mathrm{knot})\end{array}$ & $96.8-112.7$ & 485 & $393-3,509$ \\
\hline
\end{tabular}




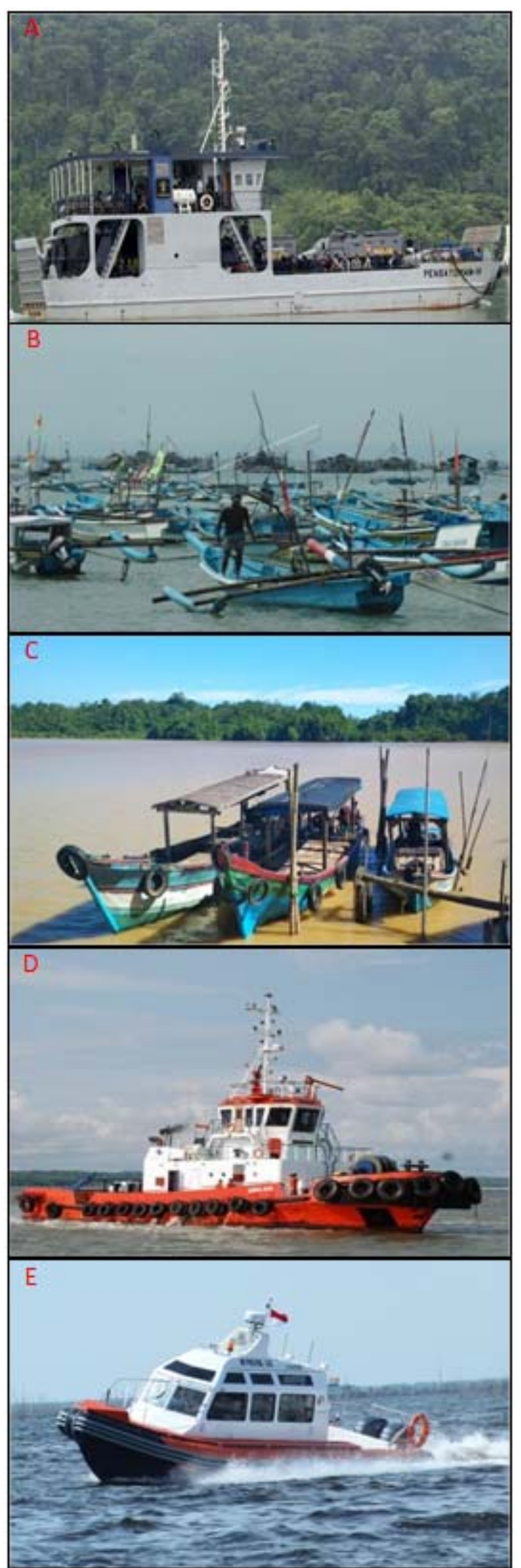

Figure 3. Type of vessels. Ro-ro ferry (A); small fishing boat (B); small ferry (C); tug boat (D); and (E) pilot boat. towing, pushing and pulling. Tugboats are also used to pull barges, damaged vessels, and other equipment. Unlike tugboats, Pilot boat have gasoline-fueled outboard engines with 2 of 250 HP and fixed propeller propulsion. The size of the vessel is also much smaller so that the load capacity only reaches $3.5 \mathrm{GT}$. With a smaller size and considerable engine power, it can be operated at a very high speed of up to 30 knots. This boat is used to arrange or pick-up guide officers who will guide or finish guiding. Pilot boat is able to maintain maneuver stability, equipped with adequate navigation tools and radio communication.

Differences in the function of each ship provide differences in ship size, type and engine strength, loading power and operational speed of the vessel which influences differences in the sound characteristics it produces. Noise characteristics are closely related to engine type, propulsion system and propeller (Ross, 2005) because the ships sound source comes from propeller, main engine, auxiliary engine, flow noise, etc. (Pazara et al., 2018). The mechanism of sound production system of the ship also affects the sound characteristics, where the mechanism depends largely on the characteristics of the ship and its engine type (McKenna et al., 2012). Its related to the sound of the ship produced is a combination of propeller cavitation, hydrodynamic and mechanical noise (Hildebrand, 2009). Small vessels equipped with engines and propellers at high speeds will produce higher noise (Erbe, 2002). While the large ship will produce low frequency noise due to its large size and equipped with lower engine RPM and propeller (McKenna et al., 2012). When the ship is operated, noise cavitation will increase as the ships speed, size and load increase (Donald Ross \& Kuperman, 1989; Scrimger \& Heitmeyer, 1991; Hamson, 1997; Trevorrow et al., 2008).

\subsection{Noise characteristics of vessels \\ Noise characteristics both frequency and} sound pressure level (SPL) are varied by type of vessels (Table 1). The noise frequency of all the vessel types recorded ranged from low frequencies $(170 \mathrm{~Hz})$ to high frequency that almost reached $20 \mathrm{kHz}$ with peak frequency ranging from $347-1.742 \mathrm{~Hz}$. Meanwhile, sound pressure levels did not vary greatly for the five vessels, believed to range from $93.8-117.8 \mathrm{~dB}$ re $1 \mu \mathrm{Pa}$. The difference in frequency and sound pressure level of each vessel is related to the differences in engines type and power, load capacity, and operation speed. 
The highest contribution to frequency of noise as a source of pollution in the Nusakambangan Strait comes from small ferry, where it has two frequency ranges, below 3,189 $\mathrm{Hz}$ and $12,150-19,950 \mathrm{~Hz}$ with peaks in the lower frequency range $(3,181 \mathrm{~Hz})$. The existence of two frequency range is caused by the difference in sound source of both, where the lower range comes from the engine and the upper range by other sound sources such as propeller and flow noise recorded by hydrophone. This ship has the highest frequency of other types because it is equipped with gasoline-fuelled outboard engine. The type of vessel with the same type of engine (small fishing and pilot boats) has a frequency that includes higher than the other two ships of different engine types, each in the range of 777 $-6,795 \mathrm{~Hz}$ and $393-3,509 \mathrm{~Hz}$. Although the three types of vessels have the same type of engine but the loading capacity of each ship is different. This is closely related to the sound emitted by these ships, where the largest loading capacity is small ferry which impacts on the frequency produced is also highest among others. Unlike the three types of vessels, ro-ro ferry and tug boat are equipped with dieselfuelled inboard engine so that they are closely related to the noise frequency emitted lower than other types of vessels (below $3 \mathrm{kHz}$ ). Tug boat has a relatively lower frequency with a peak of $347 \mathrm{~Hz}$ because this ship has a lower loading capacity compared to ro-ro ferry. The information from the vessels indicates that the frequency of its noise is closely related to the type of engine and loading capacity.

The difference in frequency of vessel was not immediately followed by the difference in SPL, where the highest noise intensity was produced by tug boats reaching $117.8 \mathrm{~dB}$ re $1 \mu \mathrm{Pa}$ and roro ferry with a range of $102.0-115 \mathrm{~dB}$ re $1 \mu \mathrm{Pa}$. The type of diesel-fuelled inboard engine although has a lower frequency but the SPL is higher than other engine types. Although the tug boat has the same engine type as the ro-ro ferry, it has much higher power so it is closely related to the difference in noise intensity that produced. SPL variation of tug boat and other vessel type due to difference in speed and distance to receiver position. Other types of vessels (small fishing boat, small ferry and pilot boat) with gasoline-fuelled inboard engine although both have lower noise intensity compared to ships with other engine types, but differences in engine power and operating speed make a few differences to the SPL. Pilot boat with $500 \mathrm{HP}$ engine power operated with 30 knots of exhaust emits noise with a range of $96.8-112.7 \mathrm{~dB}$ re 1 $\mu \mathrm{Pa}$, higher than small ferry and small fishing boat that only equipped with engine power of 25 and $15 \mathrm{HP}$ respectively with operational speeds of 8 and 12 knot. This description indicates that the SPL variation of the vessel is strongly influenced by the engines type and power, operational speed and distance of the vessel to the receiver. Specifically, the sound characteristics change on the time which recorded by the types of vessels when crossing hydrophone positions are deployed, waveform shapes show similar shapes to each other. At the beginning of which the ships noise began to be detected, the intensity of the sound was seen lower than the overall noise of the ship. The noise intensity then increases until the position of the vessel is perpendicular to the receiver position and then decreases until the noise is not detected. Waveform patterns in terms of intensity and decrease differ from one type of ship to another. In the same intensity scale, ro-ro and small ferries have similar noise intensity patterns where the signal intensity increases relative rapidly and then tends to slow down and ends with a rapid decline before the signal starts to go undetected (Figure $4 \mathrm{~A}$ and $4 \mathrm{C}$, left). Different pattern is shown by tug and pilot boats, where the intensity is rocketed when the ships will cross the receiver position (Figure 4D and 4E, left). Meanwhile, small fishing boats have their own pattern, where it increases changes relatively slowly and peaks when the ship crosses the receiver position (Figure 4C, left). This pattern is further emphasized when the waveform is lowered with envelope analysis to determine SPL (Figure 4, centre). Differences in intensity change patterns of both waveform and SPL are inseparable from the lane of each vessel. Ro-ro and small ferries have a short lane because they only cross Cilacap City with Nusakambangan Island so that the operation speed of the ferry at the beginning of leaving the pier increases rapidly and then stabilizes and decreases rapidly towards the destination pier. Tug and pilot boats have outer and inner lanes to and from Tanjung Intan Port so that the speed of the ship when going to or leaving the Port undergoes significant changes. While small fishing boat does not experience a change of speed because it only crosses the waters.

In contrast, the pattern of noise frequency change in general experience the opposite with the pattern of intensity change (Figure 4, right). A higher noise frequency at the beginning of the signal is detected and decreases until the ship crosses the receiver position and then increases until the signal is undetectable. Similar to intensity, the change in frequency is also influenced by the operation speed and distance 

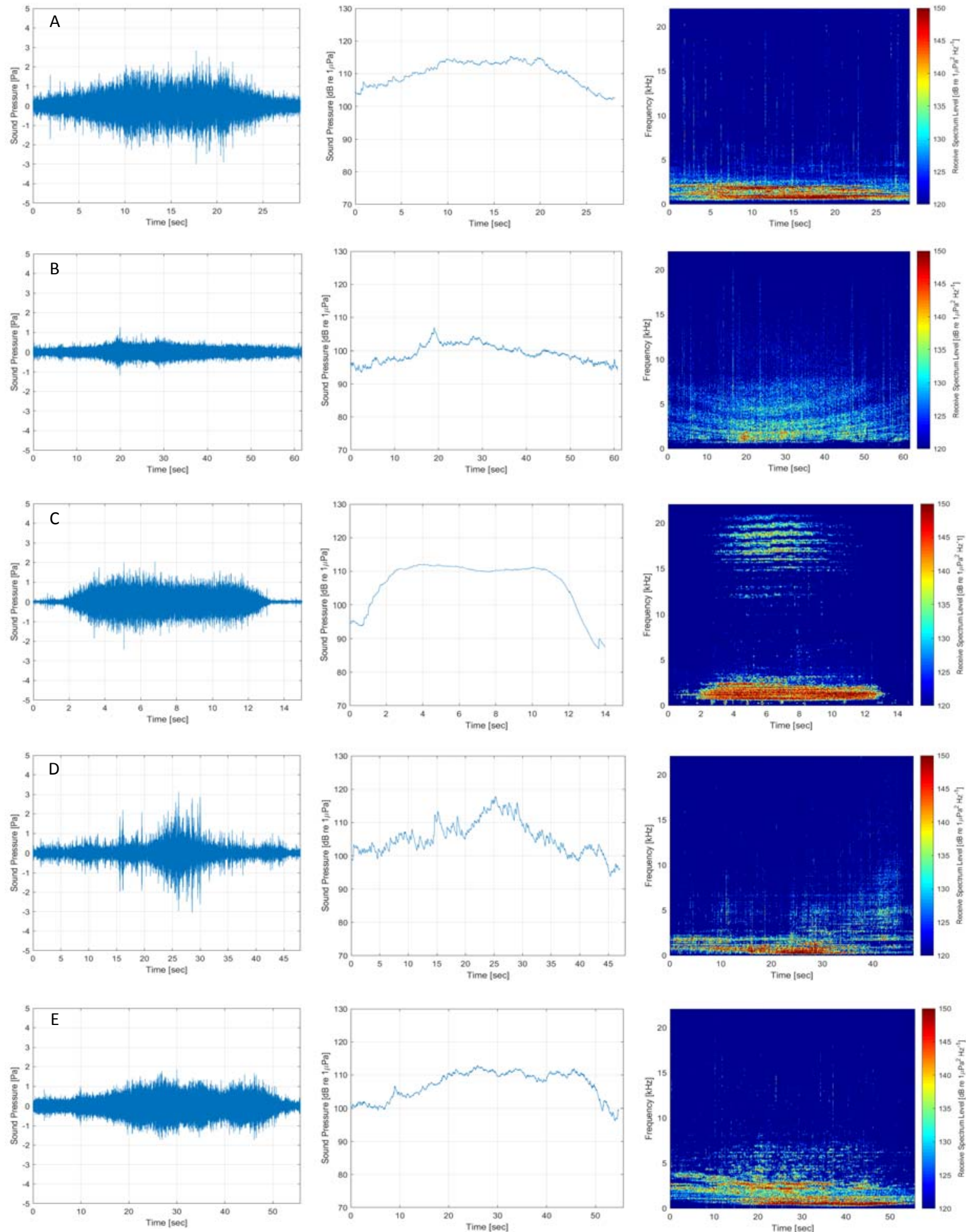

Figure 4. Noise characteristics of vessels. Left, center and right represent to waveform, sound pressure level and spectra from ro-ro ferry (A); small fishing boat (B); small ferry (C); tug boat (D); and (E) pilot boat.

of the vessel. Time-based distance changes differ from vessel to others due to differences in lane from each one. In fact, the rapid change in distance occurs in ro-ro and small ferries because the shape of the lane that only crosses the water causes the frequency change is more likely to occur quickly (Figure $4 \mathrm{~A}$ and $4 \mathrm{C}$, right). However, the difference in speed of the ferry caused a difference in frequency changes. Tug and pilot boats have relatively varied frequency 
changes due to the shape of the lane that veer when heading to or leaving the port and cause the ships operating speed to also change (Figures 4D and 4E, right). The slow change in frequency is indicated by the small fishing boat because the lane of the vessel is perpendicular and further from the receiver position (Figure 4B, right). Since the speed of the vessel does not change when crossing the waters, the change in frequency is not influenced by this parameter.

The noise characteristics produced by each type of vessel is changed based on the distance of the ship to the receiver. Differences in source intensity level and source frequency of each ship when operating influence differences in grade changes in frequency and noise intensity. Sound pressure level decreases based on distance due to acoustic propagation loss which is distance function (McKenna et al., 2012; Halliday et al., 2017; Jones et al., 2017; Enguix et al., 2019). Transmission loss is the amount of intensity lost as a result of absorption which is a function of frequency, intensity, temperature and depth (Medwin \& Clay, 1999; Simmonds \& MacLennan, 2005; Etter, 2018). Meanwhile, the frequency of noise changes due to changes in angle of ship position when operating (Fillinger et al., 2011; Peng et al., 2018; Sutin et al., 2010). The change of angle between the ship and the receiver implies an increase in frequency as a doppler effect (Dragoset, 1988; Ahmad et al., 2018).

\subsection{Noise characteristics of vessel based on the distance}

As explained earlier, noise characteristics change based on the time recorded by the hydrophone. This change is caused by a change in distance so that there is a relationship between frequency and SPL with the distance of the vessel. Frequency increases based on distance, while SPL decreases related to the increased distance (Figure 5). Although it has the same pattern that is decreasing, but the amount of frequency changes based on the distance varies between one type of ship with another (Figure 5, left). The same thing, although the pattern of intensity change is the same that decreases, but the slop of changes is differ from each other (Figure 5, right).

The highest increases in noise frequency based on distance was indicated by the ro-ro ferry with an increased coefficient of $34.28 \mathrm{~Hz} \cdot \mathrm{m}^{-1}$ for both samples of vessel (Figure $5 \mathrm{~A}$, left). It is closely related to the change of angle $(\alpha)$ which is relatively faster as a result of the ships journey according to its path to the destination pier so that the sift frequency of the receiver also changes rapidly. It is in accordance with the theory of doppler effect where the frequency received is directly proportional to the cosine $\alpha$, where the farther the distance of the vessel from the receiver, the smaller the angle formed so that the receiver frequency increases. Despite having the similar cruise lane as the ro-ro ferry, the small ferry had a lower frequency trend of $2.98 \mathrm{~Hz} \cdot \mathrm{m}^{-1}$ for both ship samples (Figure $5 \mathrm{C}$, left). It is related to the doppler effect theory, where the receiver frequency is not only affected by the a but also influenced by the speed and sources frequency of the vessel. Assuming that the speed and source frequency of the ship remains, higher the speed of the vessel, higher of receiver frequency increase because the angle formed is also smaller. The same explanation for other type of ships with different cruise lane causes the different form of noise frequency pattern based on the distance. Although tug and pilot boats have the same cruise channel but they have different frequency increases, where tug boat are higher than pilot boat with a range of 5.35 and $6.30 \mathrm{~Hz}^{-} \mathrm{m}^{-}$ 1 compared to 2.39 and $2.41 \mathrm{~Hz} \cdot \mathrm{m}^{-1}$ for each sample (Figure 5C and 5D, left). Tug boat with diesel-fuelled inboard engines have a higher noise frequency pattern than pilot boat with gasoline-fuelled inboard engines despite higher operating speed. It indicates that the source frequency factor was more dominant in influencing the increase in frequency than the speed of the vessel. The lowest trend of increasing noise frequency emitted by small fishing boats is only around 0.73 and $0.72 \mathrm{~Hz}^{-1}$ for each sample (Figure 5B, left). The vessel has the furthest lane from the receiver and with a relatively low for source frequency and speed is a great reason why this type of vessel has the lowest frequency increase than any other.

In terms of SPL, the intensity reduction pattern of each vessel type also varies with distance (Figure 5, right). Although the trend of decreased intensity is almost the same for all type of ships that range from $0.04-0.11 \mathrm{~dB}$ re 1 $\mu \mathrm{Pa} \mathrm{m}{ }^{-1}$, the steepest pattern is contributed by ro-ro ferry, small ferry and pilot boat that reaches $0.11 \mathrm{~dB}$ re $1 \mu \mathrm{Pa} \mathrm{m} \mathrm{m}^{-1}$ (Figure 5A, 5C and 5E, right). While tug and small fishing boats only had a decrease in intensity of 0.07 and $0.04 \mathrm{~dB}$ re 1 $\mu \mathrm{Pa} \mathrm{m}^{-1}$ respectively (Figure $5 \mathrm{D}$ and $5 \mathrm{~B}$, right). This trend of decreasing intensity reflects the absorption coefficient of waters that is strongly influenced by the source frequency and water conditions such as temperature and salinity. The highest source frequency by small ferry causes the absorption coefficient of vessels noise to be higher than the others. Although the source frequency of ro-ro ferry and pilot boat is insignificant compared to the other two types of 


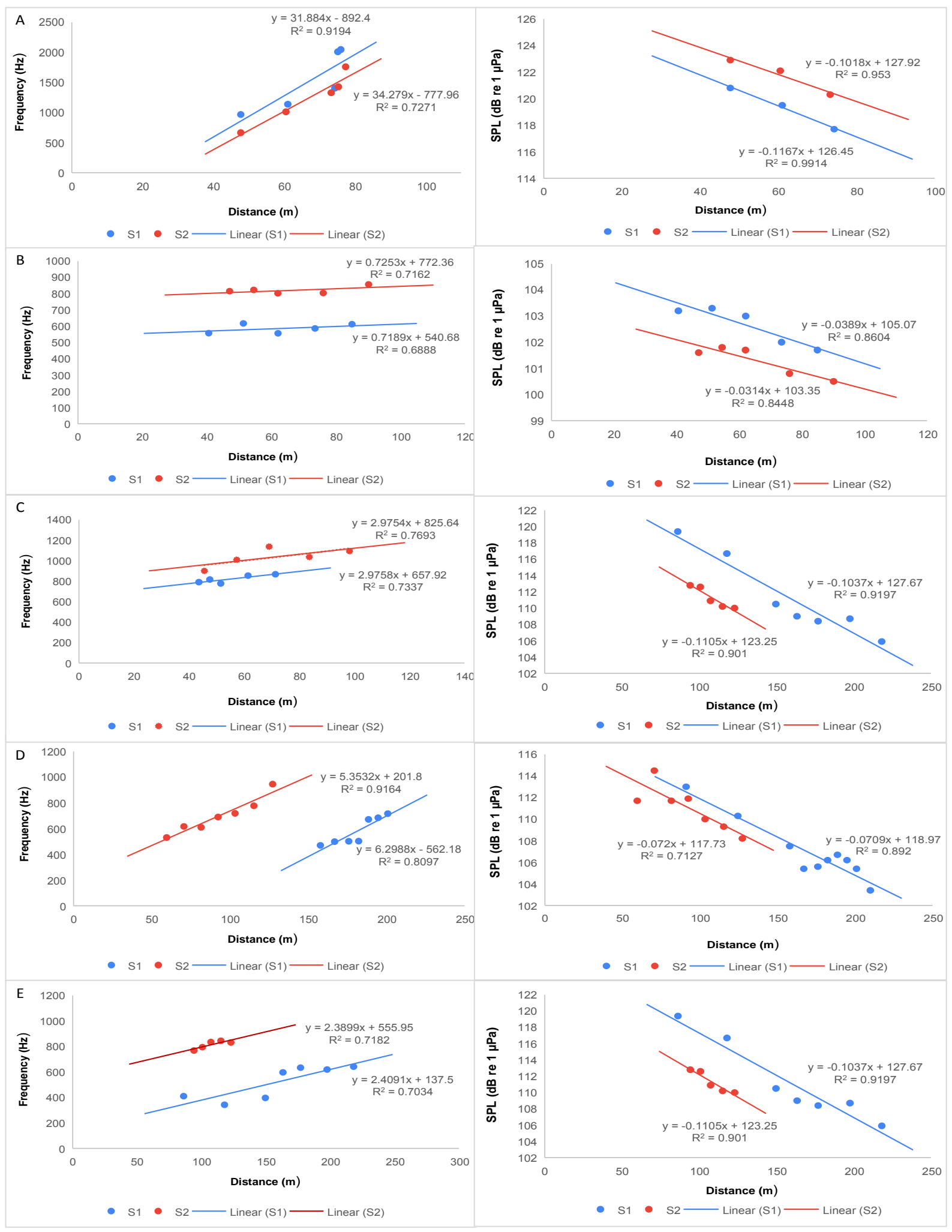

Figure 5. Relationship between frequency (left) and sound pressure level (right) to the distance of ro-ro ferry (A); small fishing boat (B); small ferry (C); tug boat (D); and (E) pilot boat. S1 and S2 represent to the camnle of veccole

vessels, the water conditions at the time of data recording are occurred at high tide

influencing increased salinity which implies an increase in the absorption coefficient of the 
waters. While the data recording of tug and small fishing boat are occurred at low tide where the run off of freshwater from the river upstream causes salinity of the waters to decrease and indirectly influence the absorption coefficient of these waters. Temperature conditions that do not fluctuate in this strait indicates that the factor does not have a significant impact on changes in the absorption coefficient.

Another thing that can be seen from the SPL trend is the prediction of the source level of each ship type (Figure 5, right). The information of SPL data based on the distance and absorption coefficient of ships noise; source level of the ship can be predicted. The prediction results showed that the source level of ro-ro ferry, small ferry and pilot boat reached $128 \mathrm{~dB}$ re $1 \mu \mathrm{Pa}$ (Figure $5 \mathrm{~A}, 5 \mathrm{C}$ and $5 \mathrm{D}$, right). While tug and small fishing boats are only 119 and $105 \mathrm{~dB}$ re $1 \mu \mathrm{Pa}$ respectively (Figure 5D and $5 \mathrm{~B}$, right). The difference in source level based on the type of vessel is very closely related to the engines type and strength, loading capacity and operation speed of the boat. In addition to predicting source levels, this trend can also indicate the intensity of the vessel at a certain distance from the receiver.

The existence of ship noise with a frequency range of $12,150-19,950 \mathrm{~Hz}$, sound pressure level of $102.0-115 \mathrm{~dB}$ re $1 \mu \mathrm{Pa}$, and predicted source levels ranging from $105-128$ $\mathrm{dB}$ re $1 \mu \mathrm{Pa}$ has a potential impact on the presence of marine biota both fish and marine mammal. Continuous noise with the intensity range has the potential to impair behavior, masking, temporary threshold shift (TTS), recoverable injury and even mortality and potential mortal injury in endemic fish and mammal based on guidelines compiled by Popper \& Hawkins (2016). Several studies have shown that the noise of ships with such frequency and intensity ranges has a several impacts on fish (see McCauley et al., 2003; Amoser et al., 2004; Codarin et al., 2009; Wysocki et al., 2006; Kight \& Swaddle, 2011; Simpson et al., 2016; Ceraulo et al., 2021) and marine mammal (see Williams et al., 2002; Nowacek et al., 2007; Holt \& Schusterman, 2007; Branstetter \& Finneran, 2008; Christiansen et al., 2010; Wright et al., 2011; Rolland et al., 2012; Castellote et al., 2012; Allen \& Angliss, 2013; Nachtigall \& Supin, 2014; Erbe et al., 2016; Dunlop et al., 2017; Chen et al., 2017; Halliday et al., 2017; Williams et al., 2019;; Kastelein et al., 2019).

\section{Conclusion}

In conclusion, the type of commercial vessels equipped with various size, engine types and power, loading capacity, and operation speed influenced the characteristics of the noise emitted. Noise frequency based on the distance was increased, and vice versa where the intensity was decreased. Estimated source level from sound pressure level also differs based on the ship type. To complete the shortcomings in this research, further research needs to be carried out the information related to the direct impact of vessel noise on marine biota as an effort to mitigate noise pollution in these waters.

\section{Acknowledgements}

The authors are grateful to the Indonesian Ministry of Research, Technology and Higher Education (Kemenristekdikti) for financial support. the owner of MV. Perkasa 7 for the facilities, and the authority of Stasiun Pandu Pier for the access to recording data, as well as GoodLingua Proofreading for linguistic support and proofreading of the article

\section{References}

Ahmad, A. M., Barbeau, M., Garcia-Alfaro, J., Kassem, J., Kranakis, E., \& Porretta, S. (2018). Doppler effect in the underwater acoustic ultra low frequency band. Lecture Notes of the Institute for Computer Sciences, Social-Informatics and Telecommunications Engineering, LNICST, $223 \quad$ LNICST, 3-12. https://doi.org/10.1007/978-3-319-744391_1

Allen, B., \& Angliss, R. (2013). Alaska Marine Mammal Stock Assessments, 2012. NOAA Technical Memorandum, NMFS-AFSC245, https://doi.org/10.7289/V5NS0RTS

Amoser, S., Wysocki, L. E., \& Ladich, F. (2004). Noise emission during the first powerboat race in an Alpine lake and potential impact on fish communities. The Journal of the Acoustical Society of America, 116(6), 3789-3797.

Amron, A., Alam, F. C., Mukti Trenggono, M., Hidayat, R. R., \& Meinita, M. D. (2020). Noise Characteristics of Sea Waves Based on Its Height, Period and Breaking Waves. Journal Online of Physics, 5(2), 28-34. https://doi.org/10.22437/jop.v5i2.9509

Amron, Kumolo, W. A., Jaya, I., Hestirianoto, T., \& Juterzenka, K. v. (2017). Daily Sound 
Production of Terapon jorbua: Impact of Temperature and Light Condition. Journal of King Abdulaziz University: Marine Science, 27(2), 27-37. https://doi.org/10.1051/alr

Amron, A., Jaya, I., Hestirianoto, T., \& von Juterzenka, K. (2018). Sound characteristics of Terapon Fish (Terapon jorbua) as a response to temperature changes. International Journal of Environmental Science and Technology, 15(11), 2493-2498.

Arveson, P. T., \& Vendittis, D. J. (2000). Radiated noise characteristics of a modern cargo ship. The Journal of the Acoustical Society of America, 107(1), 118-129. https://doi.org/10.1121/1.428344

Blackwell, S. B., \& Greene, C. R. (2006). Sounds from an oil production island in the Beaufort Sea in summer: Characteristics and contribution of vessels. The Journal of the Acoustical Society of America, 119(1), 182-196.

https://doi.org/10.1121/1.2140907

Branstetter, B. K., \& Finneran, J. J. (2008). Comodulation masking release in bottlenose dolphins ( Tursiops truncatus ). The Journal of the Acoustical Society of America, 124(1), 625-633. https://doi.org/10.1121/1.2918545

Bussmann, K., Utne-Palm, A. C., \& de Jong, K. (2020). Sound production in male and female corkwing wrasses and its relation to visual behaviour. Bioacoustics, 00(00), 123.

https://doi.org/10.1080/09524622.2020.18 38324

Casper, B. M., Smith, M. E., Halvorsen, M. B., Sun, H., Carlson, T. J., \& Popper, A. N. (2013). Effects of exposure to pile driving sounds on fish inner ear tissues. Comparative Biochemistry and Physiology Part A: Molecular \& Integrative Physiology, 166(2), 352-360.

Castellote, M., Clark, C. W., \& Lammers, M. O. (2012). Acoustic and behavioural changes by fin whales (Balaenoptera physalus) in response to shipping and airgun noise. Biological Conservation, 147(1), 115-122. https://doi.org/10.1016/j.biocon.2011.12.02 1

Ceraulo, M., Sal Moyano, M. P., Hidalgo, F. J., Bazterrica, M. C., Mazzola, S., Gavio, M. A., \& Buscaino, G. (2021). Boat Noise and Black Drum Vocalizations in Mar Chiquita
Coastal Lagoon (Argentina). Journal of Marine Science and Engineering, 9(1), 44. https://doi.org/10.3390/jmse9010044

Chen, F., Shapiro, G. I., Bennett, K. A., Ingram, S. N., Thompson, D., Vincent, C., Russell, D. J. F., \& Embling, C. B. (2017). Shipping noise in a dynamic sea: a case study of grey seals in the Celtic Sea. Marine Pollution Bulletin, 114(1), 372-383.

Christiansen, F., Lusseau, D., Stensland, E., \& Berggren, P. (2010). Effects of tourist boats on the behaviour of Indo-Pacific bottlenose dolphins off the south coast of Zanzibar. Endangered Species Research, 11(1), 9199. https://doi.org/10.3354/esr00265

Codarin, A., Wysocki, L. E., Ladich, F., \& Picciulin, M. (2009). Effects of ambient and boat noise on hearing and communication in three fish species living in a marine protected area (Miramare, Italy). Marine Pollution Bulletin, 58(12), 1880-1887.

Di Franco, E., Pierson, P., Di lorio, L., Calò, A., Cottalorda, J. M., Derijard, B., Di Franco, A., Galvé, A., Guibbolini, M., Lebrun, J., Micheli, F., Priouzeau, F., Risso-de Faverney, C., Rossi, F., Sabourault, C., Spennato, G., Verrando, P., \& Guidetti, P. (2020). Effects of marine noise pollution on Mediterranean fishes and invertebrates: A review. Marine Pollution Bulletin, 159, 111450.

https://doi.org/https://doi.org/10.1016/j.mar polbul.2020.111450

Dragoset, W. H. (1988). Marine vibrators and the doppler effect. Proceedings of the Annual Offshore Technology Conference, 1988May(11), 227-234. https://doi.org/10.4043/5642-ms

Dunlop, R. A., Noad, M. J., McCauley, R. D., Scott-Hayward, L., Kniest, E., Slade, R., Paton, D., \& Cato, D. H. (2017). Determining the behavioural doseresponse relationship of marine mammals to air gun noise and source proximity. Journal of Experimental Biology, 220(16), 2878-2886.

https://doi.org/10.1242/jeb.160192

Enguix, I. F., Egea, M. S., González, A. G., \& Serrano, D. A. (2019). Underwater acoustic impulsive noise monitoring in port facilities: Case study of the port of cartagena. Sensors (Switzerland), 19(21). https://doi.org/10.3390/s19214672

Erbe, C. (2002). Underwater noise of whalewatching boats and potential effects on 
killer whales (Orcinus orca), based on an acoustic impact model. Marine Mammal Science, 18(2), 394-418.

Erbe, C., Reichmuth, C., Cunningham, K., Lucke, K., \& Dooling, R. (2016). Communication masking in marine mammals: A review and research strategy. Marine Pollution Bulletin, 103(1-2), 15-38.

Etter, P. C. (2018). Underwater acoustic modeling and simulation, fifth edition. In Underwater Acoustic Modeling and Simulation, Fifth Edition. https://doi.org/10.1201/9781315166346

Fillinger, L., Sutin, A., \& Sedunov, A. (2011). Acoustic ship signature measurements by cross-correlation method. The Journal of the Acoustical Society of America, 129(2), 774-778. https://doi.org/10.1121/1.3365315

Halliday, W. D., Insley, S. J., Hilliard, R. C., de Jong, T., \& Pine, M. K. (2017). Potential impacts of shipping noise on marine mammals in the western Canadian Arctic. Marine Pollution Bulletin, 123(1-2), 73-82.

Halliday, W. D., Pine, M. K., \& Insley, S. J. (2020). Underwater noise and Arctic marine mammals: review and policy recommendations. Environmental Reviews, 28(4), 438-448.

Hamson, R. M. (1997). The modelling of ambient noise due to shipping and wind sources in complex environments. Applied Acoustics, 51(3), 251-287.

Hatch, L., Clark, C., Merrick, R., Van Parijs, S., Ponirakis, D., Schwehr, K., Thompson, M., \& Wiley, D. (2008). Characterizing the relative contributions of large vessels to total ocean noise fields: A case study using the Gerry E. studds stellwagen bank national marine sanctuary. Environmental Management, 42(5), 735-752. https://doi.org/10.1007/s00267-008-9169-4

Hildebrand, J. (2004). Impacts of anthropogenic sound on cetaceans. Unpublished Paper Submitted to the International Whaling Commission Scientific Committee SC/56 E, 13.

Hildebrand, J. A. (2009). Anthropogenic and natural sources of ambient noise in the ocean. Marine Ecology Progress Series, 395, 5-20.

Holt, M. M., \& Schusterman, R. J. (2007). Spatial release from masking of aerial tones in pinnipeds. The Journal of the Acoustical
Society of America, 121(2), 1219-1225. https://doi.org/10.1121/1.2404929

Jones, E. L., Hastie, G. D., Smout, S., Onoufriou, J., Merchant, N. D., Brookes, K. L., \& Thompson, D. (2017). Seals and shipping: quantifying population risk and individual exposure to vessel noise. Journal of Applied Ecology, 54(6), 1930-1940. https://doi.org/10.1111/1365-2664.12911

Kastelein, R. A., von Benda-Beckmann, A. M., Lam, F. P. A., Jansen, E., \& de Jong, C. A. F. (2019). Effect of a bubble screen on the behavioral responses of captive harbor porpoises (Phocoena phocoena) exposed to airgun sounds. Aquatic Mammals, 45(6), 706-716.

https://doi.org/10.1578/AM.45.6.2019.706

Kight, C. R., \& Swaddle, J. P. (2011). How and why environmental noise impacts animals: An integrative, mechanistic review. Ecology Letters, 14(10), 1052-1061. https://doi.org/10.1111/j.14610248.2011.01664.x

Kipple, B., \& Gabriele, C. (2004). Underwater noise from skiffs to ships. Proc. of Glacier Bay Science Symposium, 172-175.

Kozaczka, E., Domagalski, J., Grelowska, G., \& Gloza, I. (2007). Identification of hydroacoustic waves emitted from floating units during mooring tests. Polish Maritime Research, 14(4), 40-46. https://doi.org/10.2478/v10012-007-0038-5

Ladich, F. (2015). Sound communication in fishes (Vol. 4). Springer.

McCauley, R. D., Fewtrell, J., \& Popper, A. N. (2003). High intensity anthropogenic sound damages fish ears. The Journal of the Acoustical Society of America, 113(1), 638-642.

https://doi.org/10.1121/1.1527962

McKenna, M. F., Gabriele, C., \& Kipple, B. (2017). Effects of marine vessel management on the underwater acoustic environment of Glacier Bay National Park, AK. Ocean and Coastal Management, 139, 102-112.

https://doi.org/10.1016/j.ocecoaman.2017. 01.015

McKenna, M. F., Ross, D., Wiggins, S. M., \& Hildebrand, J. A. (2012). Underwater radiated noise from modern commercial ships. The Journal of the Acoustical Society of America, 131(1), 92-103. https://doi.org/10.1121/1.3664100 
Medwin, H., \& Clay, C. S. (1999). Fundamentals of acoustical oceanography -- Book Review. In Fisheries Oceanography (Vol. 8, Issue 2).

Morton, A. B., \& Symonds, H. K. (2002). Displacement of Orcinus orca (L.) by high amplitude sound in British Columbia, Canada. ICES Journal of Marine Science, 59(1), https://doi.org/10.1006/jmsc.2001.1136

Nabe-Nielsen, J., Sibly, R. M., Tougaard, J., Teilmann, J., \& Sveegaard, S. (2014). Effects of noise and by-catch on a Danish harbour porpoise population. Ecological Modelling, 272, 242-251.

Nachtigall, P. E., \& Supin, A. Y. (2014). Conditioned hearing sensitivity reduction in a bottlenose dolphin (Tursiops truncatus). Journal of Experimental Biology, 217(15), 2806-2813.

https://doi.org/10.1242/jeb.104091

Nowacek, D. P., Thorne, L. H., Johnston, D. W., \& Tyack, P. L. (2007). Responses of cetaceans to anthropogenic noise. Mammal Review, 37(2), 81-115.

Pazara, T., Pricop, M., Novac, G., \& Pricop, C. (2018). The application of new noise and vibration standards onboard ships. IOP Conference Series: Earth and Environmental Science, 172(1). https://doi.org/10.1088/17551315/172/1/012027

Peng, Z., Fan, J., \& Wang, B. (2018). Analysis and modelling on radiated noise of a typical fishing boat measured in shallow water inspired by AQUO project's model. Archives of Acoustics, 43(2), 263-273. https://doi.org/10.24425/122374

Pine, M. K., Jeffs, A. G., Wang, D., \& Radford, C. A. (2016). The potential for vessel noise to mask biologically important sounds within ecologically significant embayments. Ocean and Coastal Management, 127(April), 63-73. https://doi.org/10.1016/j.ocecoaman.2016. 04.007

Popper, A. N., Fewtrell, J., Smith, M. E., \& McCauley, R. D. (2003). Anthropogenic sound: effects on the behavior and physiology of fishes. Marine Technology Society Journal, 37(4), 35-40.

Popper, A. N., \& Hawkins, A. (2016). The effects of noise on aquatic life II. Springer.

Rolland, R. M., Parks, S. E., Hunt, K. E.,
Castellote, M., Corkeron, P. J., Nowacek, D. P., Wasser, S. K., \& Kraus, S. D. (2012). Evidence that ship noise increases stress in right whales. Proceedings of the Royal Society B: Biological Sciences, 279(1737), 2363-2368.

Ross, D. (2005). Ship sources of ambient noise. IEEE Journal of Oceanic Engineering, 30(2), 257-261. https://doi.org/10.1109/JOE.2005.850879

Ross, Donald, \& Kuperman, W. A. (1989). Mechanics of underwater noise. Acoustical Society of America.

Sanjana, M. C., Latha, G., Thirunavukkarasu, A., Rajendran, V., \& Des, A. (2010). Fluctuation and variability of shallow water ambient noise from time series measurements. Fluctuation and Noise Letters, $\quad$ 9(2), 193-202. https://doi.org/10.1142/S0219477510000174

Scrimger, P., \& Heitmeyer, R. M. (1991). Acoustic source-level measurements for a variety of merchant ships. The Journal of the Acoustical Society of America, 89(2), 691-699.

Simmonds, J., \& MacLennan, D. (2005). Fisheries Acoustics: Teory and Practice. In Balckwell Science. https://doi.org/10.1007/978-1-4899-01361_14

Simpson, S. D., Radford, A. N., Holles, S., Ferarri, M. C. O., Chivers, D. P., McCormick, M. I., \& Meekan, M. G. (2016). Small-boat noise impacts natural settlement behavior of coral reef fish larvae. Advances in Experimental Medicine and Biology, 875(December), 1041-1048. https://doi.org/10.1007/978-1-4939-29818_129

Soares, C., Pacheco, A., Zabel, F., GonzálezGoberña, E., \& Sequeira, C. (2020). Baseline assessment of underwater noise in the Ria Formosa. Marine Pollution Bulletin, 150, 110731.

Sutin, A., Bunin, B., Sedunov, A., Sedunov, N., Fillinger, L., Tsionskiy, M., \& Bruno, M. (2010). Stevens passive acoustic system for underwater surveillance. 2010 International Waterside Security Conference, WSS 2010. https://doi.org/10.1109/WSSC.2010.57302 86

Tougaard, J., Wright, A. J., \& Madsen, P. T. (2015). Cetacean noise criteria revisited in the light of proposed exposure limits for 
harbour porpoises. Marine Pollution Bulletin, 90(1-2), 196-208.

Trevorrow, M. V., Vasiliev, B., \& Vagle, S. (2008). Directionality and maneuvering effects on a surface ship underwater acoustic signature. The Journal of the Acoustical Society of America, 124(2), 767-778.

https://doi.org/10.1121/1.2939128

Triwahyanti, L., Cyndana, A. S., Sefnianti, Y. H., Sari, R. J., \& Amron, A. (2018). Transmission Loss Estimation of Underwater Sound Based on the Noise Intensity Emmited by MV. Pengayoman IV in Tanjung Intan Cruise Line, Cilacap. E3S Web of Conferences, 47, 4011.

Vargas-Salinas, F., \& Amézquita, A. (2014). Abiotic noise, call frequency and streambreeding anuran assemblages. Evolutionary Ecology, 28(2), 341-359. https://doi.org/10.1007/s10682-013-9675-6

Viola, S., Grammauta, R., Sciacca, V., Bellia, G., Beranzoli, L., Buscaino, G., Caruso, F., Chierici, F., Cuttone, G., D'Amico, A., De Luca, V., Embriaco, D., Favali, P., Giovanetti, G., Marinaro, G., Mazzola, S., Filiciotto, F., Pavan, G., Pellegrino, C., ... Riccobene, G. (2017). Continuous monitoring of noise levels in the Gulf of Catania (Ionian Sea). Study of correlation with ship traffic. Marine Pollution Bulletin, 121(1-2),

97-103. https://doi.org/10.1016/j.marpolbul.2017.05. 040

Williams, K. L., Jackson, D. R., Thorsos, E. I., Tang, D., \& Schock, S. G. (2002). Comparison of sound speed and attenuation measured in a sandy sediment to predictions based on the Biot theory of porous media. IEEE Journal of Oceanic Engineering, 27(3), 413-428.

Williams, R., Veirs, S., Veirs, V., Ashe, E., \& Mastick, N. (2019). Approaches to reduce noise from ships operating in important killer whale habitats. Marine Pollution Bulletin, 459-469. https://doi.org/10.1016/j.marpolbul.2018.0 5.015

Wright, A. J., Deak, T., \& Parsons, E. C. M. (2011). Size matters: Management of stress responses and chronic stress in beaked whales and other marine mammals may require larger exclusion zones. Marine Pollution Bulletin, 63(1-4), 5-9. https://doi.org/10.1016/j.marpolbul.2009.1 1.024

Wysocki, L. E., Dittami, J. P., \& Ladich, F. (2006). Ship noise and cortisol secretion in European freshwater fishes. Biological Conservation, 128(4), 501-508. https://doi.org/10.1016/j.biocon.2005.10.02 0

Zhang, C., Liu, Y., Shang, D., \& Khan, I. U. (2020). A method for predicting radiated acoustic field in shallow sea based onwave superposition and ray. Applied Sciences (Switzerland), 10(3). https://doi.org/10.3390/app10030917

Zhang, L., \& Meng, C. (2018). Modeling of Radiated Noise Passing Characteristic for Ship in Different Marine Environments. 160(Msam), $36-39$. https://doi.org/10.2991/msam-18.2018.8 